\title{
PENERAPAN MODEL STUDENT TEAM ACHIEVEMENT DIVISION (STAD) PADA PEMBELAJARAN MATEMATIKA SISWA KELAS VIII SMP NEGERI 2 SALING
}

\author{
Malik Hidayat $^{1}$, Sukasno ${ }^{2}$, Efuansyah $^{3}$

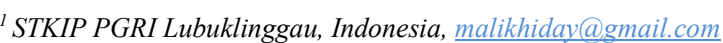 \\ ${ }^{2}$ STKIP PGRI Lubuklinggau, Indonesia, sukasno@stkippgri-lubuklinggau.ac.id \\ ${ }^{3}$ STKIP PGRI Lubuklinggau, Indonesia, efuansyah@stkippgri-lubuklinggau.ac.id
}

\section{ARTICLE INFORMATION \\ Received: November 11, 2020 \\ Revised: December 20, 2020 \\ Available online: December 31, 2020}

\section{KEYWORDS}

Penerapan, STAD, Hasil Belajar, Matematika

Application, STAD, Learning Outcomes, Mathematics

CORRESPONDENCE

\section{Malik Hidayat}

E-mail:

malikhiday@gmail.com

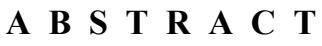

Penelitian ini bertujuan untuk mengetahui ketuntasan hasil belajar matematika siswa kelas VIII SMP Negeri 2 Saling tahun ajaran 2020/2021 setelah diterapkan model pembelajaran Student Team Achievement Division (STAD). Jenis penelitian ini adalah Pre-Experimen Design dengan desain berbentuk pre-test and post-test group. Populasi dalam penelitian ini adalah seluruh siswa kelas VIII SMP Negeri 2 Saling tahun ajaran 2020/2021 yang berjumlah 54 siswa dan sebagai sampel penelitian yaitu kelas VIII.A kelompok belajar satu yang berjumlah 12 siswa. Pengumpulan data dilakukan dengan teknik tes, yaitu pre-test dan post-test. Data yang terkumpul dianalisis menggunakan uji-t pada taraf signifikan $\alpha=0,05$. Berdasarkan hasil analisis uji-t dengan taraf signifikansi $\alpha=0,05$, diperoleh $t_{\text {hitung }}(5,9495)>t_{\text {tabel }}(2,201)$, sehingga dapat disimpulkan bahwa bahwa hasil belajar matemaika siswa kelas VIII SMP Negeri 2 Saling setelah diterapkan dengan model pembelajaran Student Team Achievement Division (STAD) secara signifikan tuntas.
\end{abstract}

This study aims to determine the completeness of the mathematics learning outcomes of class VIII students of SMP Negeri 2 Saling in the 2020/2021 academic year after the Student Team Achievement Division (STAD) learning model is applied. This type of research is a pre-experimental design with a pretest and post-test group design. The population in this study were all students of class VIII SMP Negeri 2 Saling in the academic year 2020/2021, totaling 54 students and as the research sample, namely class VIII.A one study group totaling 12 students. The data was collected by using test techniques, namely pre-test and post-test. The collected data were analyzed using t-test at the significant level $\alpha=0.05$. Based on the results of the t-test analysis with a significance level of $\alpha=0.05$, it was obtained tcount (5.9495)> ttable (2.201), so it can be concluded that the mathematics learning outcomes of class VIII students of SMP Negeri 2 Saling after being applied with the Student Team learning model Achievement Division (STAD) is significantly complete.

\section{PENDAHULUAN}

Matematika merupakan mata pelajaran yang diberikan pada setiap jenjang pendidikan. Matematika adalah suatu ilmu yang dapat meningkatkan kemampuan berpikir dan berargumentasi, memberikan kemudahan dalam menyelesaikan masalah sehari-hari dan maupun dalam dunia kerja, serta dukungan dalam mengembangkan ilmu pengetahuan dan teknologi (Susanto, 2016: 185). 


\section{Journal of Mathematics Science and Education \\ ISSN (Print) 2623-2375 | ISSN (Online) 2623-2383 | \\ DOI : https://doi.org/10.31540/jmse.v3i1.1059 \\ Penerbit : LP4MK STKIP PGRI Lubuklinggau}

Menurut Mustika \& Buana (2017: 30) pembelajaran matematika merupakan proses pemberian pengalaman belajar kepada siswa melalui serangkaian kegiatan terencana sehingga siswa memperoleh kompetensi tentang bahan matematika yang diperoleh.

Dalam pembelajaran matematika banyak siswa yang mengalami berbagai kendala dalam memahaminya. Seperti yang dikutip oleh Herdian (Ulvah \& Afriansyah, 2016: 143), salah satu kendala yang dialami siswa dalam pembelajaran matematika dikarenakan kurangnya pemahaman dan ketertarikan siswa pada pelajaran matematika. Hal ini terjadi dikarenakan adanya suatu kondisi dimana dalam pembelajaran matematika siswa kurang dilibatkan dalam proses pembelajaran, serta sebagian siswa sudah terlanjur beranggapan bahwa pelajaran matematika merupakan pelajaran yang sulit sehingga siswa pun menjadi enggan untuk belajar matematika. Dengan demikian hal ini akan berpengaruh pada rendahnya hasil belajar siswa dalam pembelajaran matematika. Menurut Susanto (2016:05) hasil belajar siswa adalah kemampuan yang diperoleh anak setelah melalui kegiatan belajar. Karena belajar itu merupakan suatu proses dimana seseorang berusaha untuk memperoleh suatu bentuk perubahan perilaku yang relatif menetap.

Berdasarkan hasil observasi yang peneliti lakukan di SMP Negeri 2 Saling diketahui bahwa pembelajaran yang digunakan oleh guru matematika kelas VIII yaitu menggunakan pembelajaran konvensional, dimana siswa belajar hanya senantiasa mengikuti apa yang diajarkan guru saja, sehingga kemampuan siswa dalam bekerjasama maupun keberanian dalam mengungkapkan ide atau gagasan yang mereka miliki juga kurang. Selain itu berdasarkan informasi hasil wawancara dengan guru matematika dan siswa kelas VIII SMP Negeri 2 Saling bahwa sebagian besar siswa kurang aktif dalam mengikuti pembelajaran matematika, siswa mengalami kesulitan dalam mengerjakan soal latihan yang berbeda dengan contoh soal yang diberikan.

Dilihat dari hasil Ujian Semester Genap tahun pelajaran 2019/2020 SMP Negeri 2 Saling nilai rata-rata matematika siswa kelas VIII yaitu 49,70. Sedangkan Kriteria Ketuntasan Minimal (KKM) yang ditetapkan adalah 60. Dari 54 jumlah siswa kelas VIII yang ada, siswa yang telah mencapai nilai KKM sebanyak 35,2\% yaitu 19 siswa, sedangkan siswa yang belum mencapai nilai KKM sebanyak 64,8\% yaitu 35 siswa. Hal ini menunjukkan bahwa hasil belajar yang diperoleh siswa dalam pelajaran matematika masih sangat rendah. Dengan demikian diperlukan perhatian dan perbaikan dalam proses pembelajaran matematika untuk membuat siswa menghilangkan anggapan bahwa pelajaran matematika merupakan pelajaran yang sulit sehingga siswa lebih menyukai pelajaran matematika dan hasil belajar siswa dalam pelajaran matematika meningkat dan tuntas. 


\section{Journal of Mathematics Science and Education \\ ISSN (Print) 2623-2375 | ISSN (Online) 2623-2383 | \\ DOI : https://doi.org/10.31540/jmse.v3i1.1059 \\ Penerbit : LP4MK STKIP PGRI Lubuklinggau}

Dengan adanya permasalahan tersebut, dalam hal ini guru hendaknya dapat membantu siswa dalam memahami pembelajaran matematika dalam meningkatkan hasil belajar siswa pada pembelajaran matematika. Upaya yang dapat dilakukan guru dalam proses kegiatan belajar untuk meningkatkan hasil belajar siswa yaitu dengan menggunakan model pembelajaran Student Team Achievement Division (STAD). Hal ini sesuai dengan pendapat Putri (2018:130) yang menyatakan bahwa Model STAD merupakan salah satu model pembelajaran inovatif yang dapat memberikan kondisi belajar aktif pada siswa sehingga siswa dapat memperoleh pengetahuan yang lebih bermakna dan dapat meningkatkan hasil belajar. Wardana (2017:79) juga mengatakan bahwa dengan menggunakan model pembelajaran STAD siswa mampu menciptakan interaksi lebih luas, sehingga siswa akan termotivasi untuk ikut aktif di dalam proses pembelajaran.

Model pembelajaran STAD merupakan model pembelajaran yang mengacu kepada belajar kelompok siswa, menyajikan informasi akademik baru kepada siswa setiap minggu menggunakan presentasi verbal atau teks dan dalam suatu kelas tertentu dipecah menjadi kelompok dengan beranggotakan 4-5 orang secara heterogen yang terdiri dari laki-laki dan perempuan, berasal dari berbagai suku, memiliki kemampuaan tinggi, sedang, dan rendah (Shoimin, 2014:185). Sedangkan menurut Suyatno (2009:52), model pembelajaran STAD adalah pembelajaran kooperatif untuk pengelompokkan kemampuan campuran yang melibatkan pengakuaan tim dan tanggung jawab kelompok untuk pembelajaran individu anggota. Kegiatan pembelajaran pada model pembelajaran STAD memberi kesempatan kepada siswa untuk dapat bekerjasama sehingga siswa berani dan mampu dalam mengungkapkan ide atau gagasan dan siswa manjadi lebih aktif. Dengan demikian dengan model pembelajaran $S T A D$ diharapkan dapat meningkatkan hasil belajar siswa dalam pembelajaran matematika.

Tujuan penelitian ini adalah untuk mengetahui penerapan model Student Team Achievement Division (STAD) pada pembelajaran matematika siswa kelas VIII SMP Negeri 2 Saling.

\section{METODE}

Metode yang digunakan dalam penelitian ini adalah Pre-Experimen Design. Pre-Experimen Design yaitu eksperimen yang sering dipandang sebagai eksperimen yang tidak sebenarnya. (Arikunto, 2010:123). Menurut Arikunto (2010:124) desain pre-test and post-test group dilakukan sebanyak dua kali yaitu sebelum eksperimen dan sesudah. Adapun desain eksperimen menurut Arikunto (2010:124) dapat di gambarkan: 


\section{Journal of Mathematics Science and Education \\ | ISSN (Print) 2623-2375 | ISSN (Online) 2623-2383 | \\ DOI : https://doi.org/10.31540/imse.v3i1.1059 \\ Penerbit : LP4MK STKIP PGRI Lubuklinggau}

\section{Pola: $\mathbf{O}_{1} \mathbf{X} \quad \mathbf{O}_{2}$}

Keterangan:

$\mathbf{0}_{\mathbf{1}}$ : Pre-test (tes yang dilakukan sebelum eksperimen).

$\mathbf{X}$ :Perlakuan dengan model Student Team Achievement Division

$\mathbf{O}_{2}:$ Post-test (tes sesudah eksperimen dilakukan).

Lokasi yang diambil peneliti dalam penelitianya adalah di SMP Negeri 2 Saling yakni pada kelas VIII. Penelitian mengenai penerapan model Student Team Achievement Division pada pembelajaran matematika siswa kelas VIII SMP Negeri 2 Saling dilaksanakan pada bulan Juli sampai dengan Agustus semester ganjil tahun ajaran 2020/2021. Teknik sampling merupakan teknik pengambilan sampel (Sugiyono, 2011:62). Teknik pengambilan sampel yang digunakan dalam penelitian ini adalah Random sampling (teknik acak). Teknik ini dilakukan karena setiap kelas dari seluruh subjek mempunyai kesempatan yang sama untuk dipilih sebagai sampel (Arikunto, 2010:177). Teknik pengambilan sampel dilakukan dengan cara undian. Mengingat dalam kondisi pandemi covid-19 maka setiap kelas dibagi menjadi 2 kelas sehingga kelas VIII SMP Negeri 2 Saling yang sebenarnya 2 kelas, sekarang menjadi 4 kelompok belajar yaitu VIII.A kelompok belajar 1, VIII.A kelompok belajar 2, VIII.B kelompok belajar 1, dan VIII.B kelompok 2.

Adapun langkah-langkah pengambilan sampelnya dalah sebagai berikut:

a) Buat potongan kertas sebanyak empat bagian yang ukurannya sama.

b) Ke-empat potongan kertas tersebut diberi nama untuk setiap kelasnya masing-masing, yaitu VIII.A.1, VIII.A.2, VIII.B.1, dan VIII.B.2.

c) Kemudian ke-empat potongan kertas yang sudah diberi nama digulung dan dimasukkan ke dalam gelas, lalu dikocok seperti arisan.

d) Gulungan kertas yang keluar dari dalam gelas didapat kelas VIII.A.1 yang peneliti tetapkan sebagai sampel.

e) Kelas VIII.A. kelompok belajar 1 tersebut diberi pembelajaran dengan menggunakan model pembelajaran STAD.

Teknik pengumpulan data yang akan dipergunakan adalah teknik tes. Tes adalah serentetan pertanyaan atau latihan serta alat lain yang digunakan untuk mengukur keterampilan, pengetahuan inteligensi, kemampuan atau bakat yang dimiliki oleh individu atau kelompok (Arikunto, 2010:193). Teknik tes yang digunakan dalam penelitian ini adalah untuk mengetahui hasil belajar siswa setelah 


\section{Journal of Mathematics Science and Education \\ ISSN (Print) 2623-2375 | ISSN (Online) 2623-2383 | \\ DOI : https://doi.org/10.31540/jmse.v3i1.1059 \\ Penerbit : LP4MK STKIP PGRI Lubuklinggau}

diterapkan pembelajaran dengan model STAD pada meteri matematika kelas VIII SMP Negeri 2 Saling tahun ajaran 2020/2021. Teknik tes dalam penelitian ini dilakukan sebanyak dua kali yaitu tes awal (pre-test) diberikan dengan tujuan untuk melihat sejauh mana kemampuan siswa tentang materi pelajaran yang belum pernah diberikan. Sedangkan tes akhir (post-test) diberikan untuk melihat hasil belajar siswa setelah materi pelajaran diberikan. Soal tes yang akan digunakan berbentuk uraian (essay).

\section{HASIL DAN PEMBAHASAN}

Penelitian yang dilakukan ini termasuk penelitian eksperimen semu dengan tujuan untuk mengetahui hasil belajar siswa, dalam mengikuti pembelajaran dengan menggunakan model pembelajaran STAD. Pelaksanaan penelitian diawali dengan pemberian pre-test, kemudian dilanjutkan dengan kegiatan pembelajaran menggunakan model pembelajaran STAD sebanyak tiga kali pertemuan dan diakhiri dengan pemberian post-test.

\section{Kemampuan Awal Siswa (Pre-test)}

Pre-test dilaksanakan pada pertemuan pertama tanggal 27 Juli 2020 di kelas VIII.A kelompok belajar satu dengan jumlah siswa sebanyak 12 orang. Pelaksanaan pre-test dilakukan dengan tujuan untuk mengetahui hasil belajar awal siswa terkait materi pola bilangan sebelum diberi kegiatan pembelajaran dengan menggunakan model pembelajaran Student Team Achievement Division (STAD). Soal yang diberikan berbentuk uraian yang terdiri dari 5 butir soal, dimana soal tersebut sudah diketahui validitas, reliabilitas, daya pembeda dan tingkat kesukarannya. Berdasarkan hasil perhitungan (lampiran C), kemampuan pemecahan masalah siswa sebelum diberi kegiatan pembelajaran dengan menggunakan model pembelajaran Student Team Achievement Division (STAD) dapat dilihat pada Tabel 1.

Tabel 1 Rekapitulasi Hasil Pre-Test

\begin{tabular}{|c|c|c|c|c|c|}
\hline$\overline{\boldsymbol{x}}$ & $\mathbf{S}$ & Nilai Tertinggi & Nilai Terendah & Tuntas & Tidak Tuntas \\
\hline 20,56 & 9,25 & 40 & 4 & $\begin{array}{c}0 \text { siswa } \\
(0 \%)\end{array}$ & $\begin{array}{c}12 \text { siswa } \\
(100 \%)\end{array}$ \\
\hline
\end{tabular}

\section{Kemampuan Akhir Siswa (Post-test)}

Post-test dilaksanakan pada pertemuan akhir tanggal 14 Agustus 2020 di kelas VIII.A dengan jumlah siswa sebanyak 12 orang. Pemberian post-test dilakukan dengan tujuan untuk mengetahui hasil belajar matematika akhir siswa setelah mengikuti pembelajaran dengan menggunakan model 


\section{Journal of Mathematics Science and Education}

ISSN (Print) 2623-2375 | ISSN (Online) 2623-2383 |

DOI : https://doi.org/10.31540/jmse.v3i1.1059

Penerbit : LP4MK STKIP PGRI Lubuklinggau

pembelajaran Student Team Achievement Division (STAD). Berdasarkan hasil perhitungan (lampiran C), hasil belajar matematika siswa setelah mengikuti kegiatan pembelajaran dengan menggunakan model pembelajaran Student Team Achievement Division (STAD) dapat dilihat pada Tabel 2.

Tabel 2 Rekapitulasi Hasil Post-Test

\begin{tabular}{|c|c|c|c|c|c|}
\hline$\overline{\boldsymbol{x}}$ & $\mathbf{S}$ & Nilai Tertinggi & Nilai Terendah & Tuntas & Tidak Tuntas \\
\hline 76,48 & 9,59 & 91 & 60 & $\begin{array}{c}12 \text { siswa } \\
(100 \%)\end{array}$ & $\begin{array}{c}0 \text { siswa } \\
(0 \%)\end{array}$ \\
\hline
\end{tabular}

Berdasarkan Tabel 1 dapat dilihat bahwa dari 12 orang siswa yang telah mengikuti pre-test tidak ada satu pun siswa yang mendapatkan nilai dalam kategori tuntas. Rata-rata nilai hasil belajar matematika siswa sebelum diberi kegiatan pembelajaran dengan menggunakan model pembelajaran Student Team Achievement Division (STAD) adalah 20,56 artinya rata-rata hasil belajar matematika siswa termasuk kategori belum tuntas $\left(\mu_{0}<60\right)$.

Kemudian Berdasarkan Tabel 2 dapat dilihat bahwa dari 12 orang siswa yang telah mengikuti post-test, seluruh siswa mencapai rata-rata Kriteria Ketuntasan Minimal (KKM) yaitu $\geq 60$. Ratarata nilai hasil belajar matematika siswa setelah mengikuti pembelajaran dengan menggunakan model pembelajaran Student Team Achievement Division (STAD) adalah 76,48 artinya rata-rata hasil belajar matematika siswa dalam kategori tuntas.

Dengan demikian menunjukkan bahwa ada peningkatan rata-rata nilai hasil belajar matematika siswa sebelum diberi kegiatan pembelajaran yaitu dari kategori belum tuntas namun setelah mengikuti pembelajaran dengan menggunakan model pembelajaran Student Team Achievement Division (STAD) menjadi kategori tuntas, karena rata-rata nilai lebih dari atau sama dengan 60 ( $\mu_{0} \geq$ $60)$.

Dari hasil analisis diperoleh bahwa rata-rata nilai pre-test adalah 20,56 dan untuk rata-rata posttest adalah 76,48. Dengan demikian terdapat peningkatan rata-rata dari pre-test ke post-test sebesar 55,92. Sedangkan presentase jumlah siswa yang tuntas pada pre-test sebesar $0 \%$ dan pada post-test sebesar 100\%. Kemudian untuk ketuntasan belajar juga mengalami peningkatan sebesar 100\%. Secara rinci peningkatan tersebut dapat dilihat pada grafik 1: 


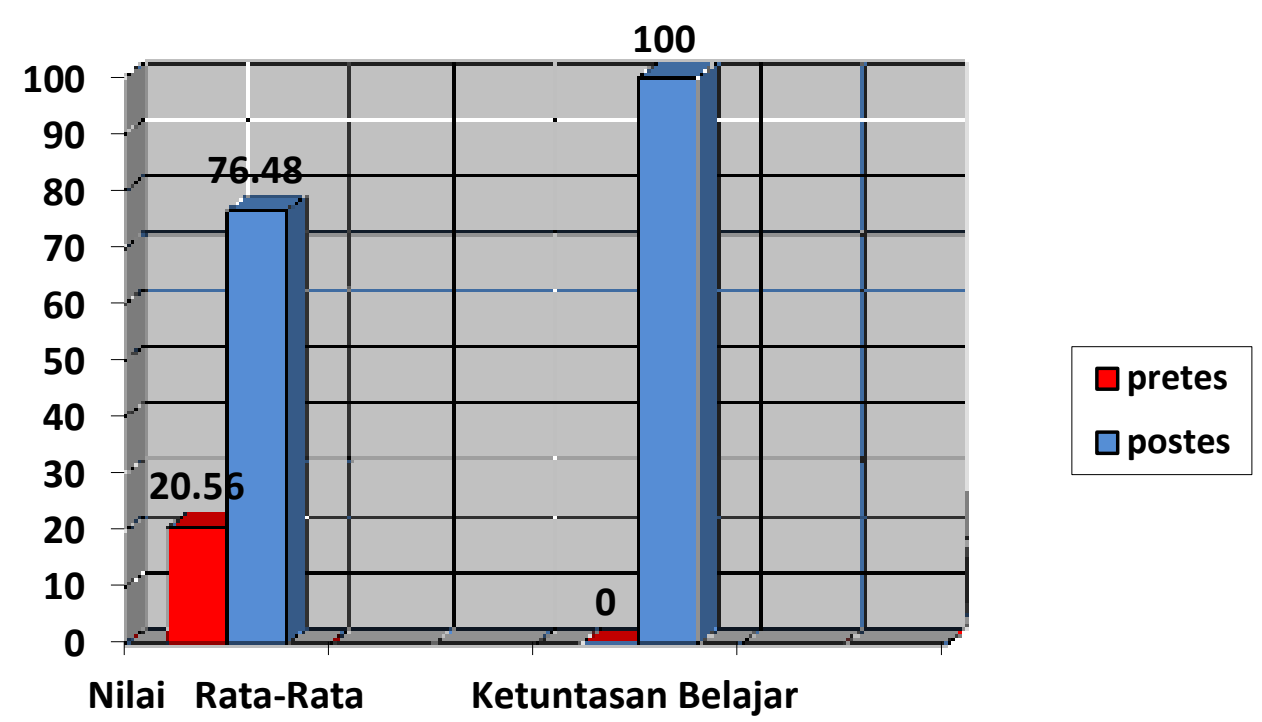

\section{Grafik 1 Rata-rata Nilai dan Ketuntasan Belajar}

\section{KESIMPULAN}

Berdasarkan rumusan masalah, hasil penelitian dan pembahasan dapat disimpulkan bahwa hasil belajar matematika siswa kelas VIII SMP Negeri 2 Saling setelah diterapkan model pembelajaran Student Team Achievement Division (STAD) yang sebelumnya rata-rata nilai pre-test adalah 20,56menjadi 76,48 pada saat post-test. Hal ini menunjukkan bahwa terdapat peningkatan yang signifikan dari pre-test ke post-test sebesar 55,92. Dari data hasil perhitungan uji hipotesis, diperoleh nilai $t_{\text {hitung }}=5,9495$ dan $t_{\text {tabel }}=2,20$,sehinggat $t_{\text {hitung }}>t_{\text {tabel }}$ maka $H_{0}$ ditolak dan $H_{a}$ diterima. Dengan demikian dapat disimpulkan bahwa hasil belajar siswa kelas VIII SMP Negeri 2 Saling setelah diterapkan dengan model pembelajaran Student Team Achievement Division (STAD) secara signifikan tuntas.

\section{DAFTAR RUJUKAN}

Arikunto, Suharsimi. 2010. Prosedur Penelitian Suatu Pendekatan Praktik. Jakarta: Rineka Cipta.

Mustika, Helma \& Buana, Lindra. 2017. Penerapan Model Pembelajaran Probing Prompting Terhadap Kemampuanpemecahan Masalah Matematika Siswa. Journal of Mathematics Education and Science. 2(2), 30-37. 
Putri, Ika Puspita. Keefektifan Model Pembelajaran Kooperatif Tipe Student Teams Achievement Divisions (STAD) dalam Pembelajaran Matematika. Jurnal JPSD. 4(1), 128-134.

Shoimin, Aris. 2014. 68 Model Pembelajaran Inovatif dalam Kurikulum 2013. Yogyakarta: Ar-Ruzz Media.

Sugiyono. 2011. Statistika untuk Penelitian. Bandung: Alfabeta.

Susanto, Ahmad. 2016. Teori Belajar dan Pembelajaran di Sekolah Dasar. Jakarta: Prenadamedia Group.

Suyatno. 2009. Menjelajah Pembelajaran Inovatif. Sidoarjo: Mas Media Buana Pustaka.

Ulvah, Shopia \& Afriansyah, Ekasatya Aldila. 2016. Kemampuan Pemecahan Masalah Matematis Siswa ditinjau melalui Model Pembelajaran SAVI dan Konvensional. Jurnal riset pendidikan.2(2), 142-153.

Wardana, Ika. 2017. Penerapan Model Pembelajaran Kooperatif Tipe Student Team Achivevement Division (STAD) untuk Meningkatkan Hasil belajar Siswa Kelas XI IPA Avogadro SMA Negeri 2 Pangkajene (Studi pada Materi Asam Basa). Jurnal Chemica. 18(1), 76-84. 